\title{
Effects of Origins of Soybean Meal on Growth Performance, Nutrient Retention and Excreta Microflora of Broilers
}

\author{
Yun Ku, Santosh Laxman Ingale, Jin Soo Kim, Kwang Hyun Kim, Su Hyup Lee and Byung Jo Chae ${ }^{\dagger}$ \\ College of Animal Life Sciences, Kangwon National University, Chuncheon 200-701, Republic of Korea
}

\begin{abstract}
An experiment was conducted to determine the effects of origins of soybean meal (SBM) on growth performance, nutrients and energy retention and fecal microflora in broilers. The SBM originating from Korea, Brazil and India were used. A total of 480 broiler chicks (average initial BW, $41.8 \mathrm{~g}$ ) were randomly allotted to 6 treatments. Each treatment had 4 replicate pens with 20 chicks per pen. Birds were fed diets containing SBM originated from Korea (domestic SBM), Brazil or India (imported SBM) and the diets were based on the total amino acid (TAA) or true digestible amino acid (TDAA). Experimental diets were fed in two phases, starter $(\mathrm{d} 0 \sim 21)$ and finisher $(\mathrm{d} 22 \sim 35)$. The overall weight gain, feed intake and FCR were better $(P<0.05)$ in birds fed Korean SBM. During starter and finisher periods, birds fed diets containing Korean SBM had greater $(P<0.05)$ retention of GE, DM, and CP $(P<0.05)$ as compared with Birds fed diets containing SBM from India. In addition, diets formulated on TDAA basis had grater $(P<0.05) \mathrm{CP}$ retention during starter period and DM, GE and CP retention during finisher period. There were no differences $(P>0.05)$ in the excreta microflora and overall feed cost per kg body weight gain in birds fed SBM from different origins; however, diets formulated on TDAA basis had lesser $(P<0.05)$ feed cost per kg body weight gain in birds when compared with diets formulated on TAA basis. These results indicate that Korean SBM has better nutrients digestibility than SMB originated from Brazil and India, which contributes to the improved performance of broilers. In addition, better performance was obtained when diets were formulated on TIDAA basis.
\end{abstract}

(Key words : origin of soybean meal, growth performance, nutrient digestibility, excreta microflora, economic analysis)

\section{INTRODUCTION}

Soybean-meal (SBM) is the most commonly used feed ingredient in the diet of non-ruminant animals because of its relatively high protein contents, excellent amino acid profile and dependable supply (Kim et al., 1999; Cromwell, 2000). In pigs and poultry diets, SBM account for approximately $62 \%$ of proteinaceous ingredients (ASA, 2002). Because of the good amino acid profile, SBM is usually used to balance the dietary amino acid levels with cereal grains and their byproducts in poultry feeds. United State is a leading producer of soybean (37\%), followed by Brazil (26\%), China (21\%), Argentina (17\%) and India (4\%; USDA, 2009). Unlike most plant-originated protein sources, SBM contains a relatively large amount of lysine. However, SBM is low in sulfur-containing amino acids, with methionine being the most significant limiting amino acid for poultry, followed by cystine and threonine (Eggum and Beames, 1983). Also,
SBM contains some antinutritional factors such as trypsin inhibitor, lectins and lipoxygenase (Ward, 1996). These antinutritional are destroyed by heat treatment before inclusion of SBM in poultry diets. However, improper heat treatments destroy or denature the proteins in SBM, which results in the variation in nutrients contents of SBM from different batches or origins (Araba and Dale, 1990; Lee and Garlich, 1992).

Several studies have shown considerable differences in nutrient content of SBM within and among geographic regions of the world (Baize, 1997; Grieshop et al., 2003). Because of difference in environmental conditions, genetics varieties and processing conditions, SBM chemical compositions including contents of oligosaccharides, protease inhibitors and fiber differs among different geographic regions (Baker and Stein, 2009; Kumar et al., 2010). This results in the variation in nutrient digestibility and performance of food producing animals fed SBM originated from different regions (Grieshop and Fahey, 2001; Karr-Lilienthal et al., 2005; van

\footnotetext{
${ }^{\dagger}$ To whom correspondence should be addressed : bjchae@kangwon.ac.kr
} 
Kempen et al., 2006). However, little research has been done on comparing the effects of origin of SBM on the performance and nutrients digestibility in broilers. Therefore, in this experiment, SBM obtained from three countries (Korea, Brazil and India) was evaluated for its influence on performance, nutrient retention, excreta microbial populations and economic analysis in broilers. Additionally, comparisons were made with diets formulated based on total amino acid (TAA) and true digestibility amino acid (TDAA).

\section{MATERIALS AND METHODS}

The protocol for this experiment was approved and birds were cared according to the guidelines of the Institutional Animal Care and Use Committee of Kangwon National University, Chuncheon, Republic of Korea.

\section{Birds and Diets}

A total of 480 broilers (initial BW, $41.8 \mathrm{~g}$ ) were randomly allotted to 6 treatments on the basis of BW. Each treatment had 4 replicate pens with 20 chicks per pen. Broilers were fed diets containing SBM originated from Korea (domestic), Brazil or India (imported) and the diets were based on the total amino acid (TAA) or true digestible amino acid (TDAA). Korean SBM was freshly prepared (one month before experimental feeding), while SBM imported from India and Brazil were prepared 4 months before the experimental feeding. The main objective of this experiment was to compare the effect of origin of SBM when diets containing SBM from different origins were formulated based on TAA and TDAA basis. Treatment diets containing domestic and imported (Brazil and India), were formulated based on TAA and TDAA. Experimental diets were fed in two phases, starter (d 0 21) and finisher (d 22 35). Diets for starter (Table 1) were formulated to contain 3,200 kcal/kg of ME and $23.0 \%$ of CP. Diets for finisher (Table 2) were formulated to contain 3,200 kcal/ $\mathrm{kg} \mathrm{ME}$ and $20.0 \%$ of CP. All diets met or exceeded the nutrient requirements, as suggested by the NRC (1994).

The birds were housed in rice hull-covered floor pens. Each pen was provided with a self-feeder and hanging bell drinker to allow free access to feed and water. The house temperature was maintained at $34^{\circ} \mathrm{C}$ for the first 5 days and then gradually reduced according to normal management practices, until a temperature of $23^{\circ} \mathrm{C}$ was achieved. Lighting was provided for $23 \mathrm{~h} / \mathrm{d}$.

\section{Experimental Procedures}

The pen weight (at d 1, 21 and 35) and pen feed intake (FI) was noted at the end of each phase to calculate BW gain and feed conversion ratio (FCR) for starter and finisher phases. Overall FI, BW gain, and FCR were calculated for whole duration of experiment. Two nutrient retention trials were conducted by using 2 birds from each pen by housing them in individual metabolic cages. These birds were fed the diets containing chromic oxide $(0.25 \%)$ during the last 7 days of each starter and finisher phase and excreta samples were collected for the last 3 days. The excreta samples of these birds collected over a 3 -d period were pooled to represent 1 pen. Excreta were dried in a forced-air drying oven at $60^{\circ} \mathrm{C}$ for $3 \mathrm{~d}$ and ground to pass through a 1-mm screen using a hammer mill (Buhler, Switzerland) for chemical analysis. Additionally, excreta samples were collected from each bird used for digestibility trial for microbial analysis.

\section{Chemical and Microbial Analysis}

Experimental diets and excreta samples were analyzed in triplicate for DM (Method 930.15), CP (Method 990.03), ash (method 942.05), Ca and P (Method 985.01) according to AOAC (2007) methods. Gross energy of diets and excreta were measured by a bomb calorimeter (Model 1261, Parr Instrument Co., Molin, IL), and chromium concentrations was determined with an automated spectrophotometer (Jasco V650, Jasco Corp., Tokyo, Japan) according to the procedure of Fenton and Fenton (1979).

The microbiological assay of fecal samples was carried out by the procedure suggested by Choi et al. (2011). In short, microbial groups analyzed were Clostridium spp. (Tryptose sulphite cycloserine agar), Bifidobacterium spp. (MRS agar + $0.02 \% \mathrm{NaN}_{3}+0.05 \%$ L-cystine hydrochloride monohydrate), Lactobacillus (MRS agar $+0.02 \% \mathrm{NaN}_{3}+0.05 \%$ L-cystine hydrochloride monohydrate) and coliforms (violet red bile agar). The tryptic soy agar (No. 236950), MRS agar (No. 288130), violet red bile agar (No. 216695), plate count agar 
Table 1. Formula and chemical composition of experimental starter diets (d $0 \sim 21)$

\begin{tabular}{|c|c|c|c|c|c|c|}
\hline & \multicolumn{2}{|c|}{ Korea } & \multicolumn{2}{|c|}{ Brazil } & \multicolumn{2}{|c|}{ India } \\
\hline & TAA & TDAA & TAA & TDAA & TAA & TDAA \\
\hline \multicolumn{7}{|l|}{ Ingredient } \\
\hline Corn & 51.09 & 51.50 & 50.24 & 51.19 & 52.12 & 52.54 \\
\hline Soybean meal & 39.04 & 38.75 & 40.33 & 39.44 & 38.35 & 38.07 \\
\hline Corn gluten meal & 2.00 & 2.00 & 2.00 & 2.00 & 2.00 & 2.00 \\
\hline Animal fat & 3.50 & 3.50 & 3.50 & 3.50 & 3.50 & 3.50 \\
\hline DL-Methionine $(100 \%)$ & 0.20 & 0.05 & 0.22 & 0.05 & 0.24 & 0.06 \\
\hline Choline-chloride $(50 \%)$ & 0.10 & 0.10 & 0.10 & 0.10 & 0.10 & 0.10 \\
\hline Tricalcium phosphate & 1.82 & 1.82 & 1.81 & 1.82 & 1.83 & 1.83 \\
\hline Lime stone & 1.45 & 1.48 & 1.00 & 1.10 & 1.06 & 1.10 \\
\hline Salt & 0.25 & 0.25 & 0.25 & 0.25 & 0.25 & 0.25 \\
\hline Minerals premix ${ }^{1}$ & 0.20 & 0.20 & 0.20 & 0.20 & 0.20 & 0.20 \\
\hline Vitamins premix ${ }^{2}$ & 0.20 & 0.20 & 0.20 & 0.20 & 0.20 & 0.20 \\
\hline Virginiamycin & 0.05 & 0.05 & 0.05 & 0.05 & 0.05 & 0.05 \\
\hline Salinomycin & 0.10 & 0.10 & 0.10 & 0.10 & 0.10 & 0.10 \\
\hline Total & 100.00 & 100.00 & 100.00 & 100.00 & 100.00 & 100.00 \\
\hline \multicolumn{7}{|l|}{ Chemical composition (\%) } \\
\hline $\mathrm{ME}(\mathrm{kcal} / \mathrm{kg})$ & 3,200 & 3,200 & 3,200 & 3,200 & 3,200 & 3,200 \\
\hline $\mathrm{CP}$ & 23.24 & 23.00 & 23.48 & 23.00 & 23.27 & 23.00 \\
\hline $\mathrm{Ca}$ & 1.22 & 1.23 & 1.05 & 1.08 & 1.09 & 1.10 \\
\hline Available P & 0.45 & 0.45 & 0.45 & 0.45 & 0.45 & 0.45 \\
\hline Lysine & 1.27 & 1.26 & 1.26 & 1.24 & 1.24 & 1.23 \\
\hline Methionine & 0.54 & 0.39 & 0.55 & 0.38 & 0.56 & 0.38 \\
\hline Methionine + cysteine & 0.90 & 0.75 & 0.90 & 0.73 & 0.90 & 0.72 \\
\hline Threonine & 0.87 & 0.86 & 0.87 & 0.86 & 0.85 & 0.84 \\
\hline Tryptophan & 0.21 & 0.21 & 0.21 & 0.20 & 0.21 & 0.21 \\
\hline Isoleucine & 0.97 & 0.97 & 0.93 & 0.91 & 0.89 & 0.89 \\
\hline Leucine & 2.06 & 2.05 & 2.03 & 2.01 & 2.02 & 2.02 \\
\hline Valine & 1.12 & 1.12 & 1.07 & 1.05 & 1.03 & 1.02 \\
\hline Histidine & 0.59 & 0.59 & 0.58 & 0.57 & 0.59 & 0.58 \\
\hline Arginine & 1.47 & 1.47 & 1.44 & 1.41 & 1.47 & 1.47 \\
\hline Phenylalanine & 1.21 & 1.20 & 1.19 & 1.17 & 1.17 & 1.16 \\
\hline
\end{tabular}

${ }^{1}$ Provided per kg diet: $80 \mathrm{mg} \mathrm{Fe}, 80 \mathrm{mg} \mathrm{Cu}, 100 \mathrm{mg} \mathrm{Zn,} 120 \mathrm{mg} \mathrm{Mn}, 2 \mathrm{mg} \mathrm{I}, 0.1 \mathrm{mg} \mathrm{Co}, 0.2 \mathrm{mg}$ Se.

${ }^{2}$ Provided per $\mathrm{kg}$ diet: 18,000 IU vitamin A, 3,600 IU vitamin $\mathrm{D}_{3}, 20 \mathrm{mg}$ vitamin $\mathrm{E}, 2 \mathrm{mg}$ vitamin $\mathrm{K}, 2 \mathrm{mg}$ vitamin $\mathrm{B}_{1}, 8 \mathrm{mg}$ vitamin $\mathrm{B}_{2}, 4 \mathrm{mg}$ vitamin $\mathrm{B}_{6}, 0.04 \mathrm{mg}$ vitamin $\mathrm{B}_{12}, 24 \mathrm{mg}$ pantothenic acid, $60 \mathrm{mg}$ niacin, $1 \mathrm{mg}$ folic acid and $0.06 \mathrm{mg}$ biotin. 
Table 2. Formula and chemical composition of experimental finisher diets (d 22 35)

\begin{tabular}{|c|c|c|c|c|c|c|}
\hline & \multicolumn{2}{|c|}{ Korea } & \multicolumn{2}{|c|}{ Brazil } & \multicolumn{2}{|c|}{ India } \\
\hline & TAA & TDAA & TAA & TDAA & TAA & TDAA \\
\hline \multicolumn{7}{|l|}{ Ingredient } \\
\hline Corn & 59.39 & 60.09 & 58.23 & 59.85 & 60.36 & 60.92 \\
\hline Soybean meal & 31.40 & 30.71 & 32.99 & 31.26 & 30.69 & 30.18 \\
\hline Corn gluten meal & 2.00 & 2.00 & 2.00 & 2.00 & 2.00 & 2.00 \\
\hline Animal fat & 3.00 & 3.00 & 3.00 & 3.00 & 3.00 & 3.00 \\
\hline DL-Methionine $(100 \%)$ & 0.08 & - & 0.09 & - & 0.12 & - \\
\hline Choline-chloride $(50 \%)$ & 0.10 & 0.10 & 0.10 & 0.10 & 0.10 & 0.10 \\
\hline Tricalcium phosphate & 1.36 & 1.36 & 1.34 & 1.36 & 1.36 & 1.37 \\
\hline Lime stone & 2.02 & 2.09 & 1.60 & 1.78 & 1.72 & 1.78 \\
\hline Salt & 0.25 & 0.25 & 0.25 & 0.25 & 0.25 & 0.25 \\
\hline Minerals premix ${ }^{1}$ & 0.20 & 0.20 & 0.20 & 0.20 & 0.20 & 0.20 \\
\hline Vitamins premix ${ }^{2}$ & 0.20 & 0.20 & 0.20 & 0.20 & 0.20 & 0.20 \\
\hline Total & 100.00 & 100.00 & 100.00 & 100.00 & 100.00 & 100.00 \\
\hline \multicolumn{7}{|l|}{ Chemical composition (\%) } \\
\hline ME (kcal/kg) & 3,200 & 3,200 & 3,200 & 3,200 & 3,200 & 3,200 \\
\hline $\mathrm{CP}$ & 20.34 & 20.00 & 20.73 & 20.00 & 20.30 & 20.00 \\
\hline $\mathrm{Ca}$ & 1.26 & 1.28 & 1.10 & 1.16 & 1.16 & 1.18 \\
\hline Available P & 0.35 & 0.35 & 0.35 & 0.35 & 0.35 & 0.35 \\
\hline Lysine & 1.07 & 1.05 & 1.08 & 1.04 & 1.04 & 1.03 \\
\hline Methionine & 0.39 & 0.31 & 0.40 & 0.30 & 0.41 & 0.30 \\
\hline Methionine + cysteine & 0.72 & 0.63 & 0.72 & 0.62 & 0.72 & 0.60 \\
\hline Threonine & 0.76 & 0.75 & 0.77 & 0.75 & 0.74 & 0.73 \\
\hline Tryptophan & 0.18 & 0.18 & 0.18 & 0.17 & 0.18 & 0.18 \\
\hline Isoleucine & 0.84 & 0.83 & 0.82 & 0.79 & 0.78 & 0.77 \\
\hline Leucine & 1.88 & 1.86 & 1.87 & 1.83 & 1.84 & 1.83 \\
\hline Valine & 0.98 & 0.97 & 0.95 & 0.92 & 0.91 & 0.90 \\
\hline Histidine & 0.52 & 0.51 & 0.52 & 0.50 & 0.52 & 0.51 \\
\hline Arginine & 1.26 & 1.24 & 1.24 & 1.20 & 1.26 & 1.24 \\
\hline Phenylalanine & 1.06 & 1.04 & 1.05 & 1.02 & 1.02 & 1.01 \\
\hline
\end{tabular}

${ }^{1}$ Provided per $\mathrm{kg}$ diet: 80mg Fe, $80 \mathrm{mg} \mathrm{Cu}, 100 \mathrm{mg} \mathrm{Zn,} 120 \mathrm{mg} \mathrm{Mn}, 2 \mathrm{mg} \mathrm{I}, 0.1 \mathrm{mg}$ Co, $0.2 \mathrm{mg}$ Se.

${ }^{2}$ Provided per $\mathrm{kg}$ diet: 18,000 IU vitamin A, 3,600 IU vitamin $\mathrm{D}_{3}, 20 \mathrm{mg}$ vitamin $\mathrm{E}, 2 \mathrm{mg}$ vitamin $\mathrm{K}, 2 \mathrm{mg}$ vitamin $\mathrm{B}_{1}, 8 \mathrm{mg}$ vitamin $\mathrm{B}_{2}, 4 \mathrm{mg}$ vitamin $\mathrm{B}_{6}, 0.04 \mathrm{mg}$ vitamin $\mathrm{B}_{12}, 24 \mathrm{mg}$ pantothenic acid, $60 \mathrm{mg}$ niacin, $1 \mathrm{mg}$ folic acid and $0.06 \mathrm{mg}$ biotin.

(No. 247940), and potato dextrose agar (No. 213400) used were purchased from Difco Laboratories (Detroit, MI), and
TSC agar (CM0589) was purchased from Oxoid (Hampshire, UK). 


\section{Economic Analysis}

The feed cost (FC) was calculated based on the price of ingredients used and this FC was used to calculate the feed cost per kg body weight gain (FCG) by using the following formula: $\mathrm{FCG}=\mathrm{TFI} \times \mathrm{FC} / \mathrm{TWG}$; $\mathrm{TFI}=$ total feed intake and $\mathrm{TWG}=$ total weight gain per broiler $(\mathrm{kg})$.

\section{Statistical Analysis}

Statistical analysis was conducted by using the GLM procedure of SAS (1996). Pens were used as the experimental unit for all the parameters. An independent $t$-test was used to compare among SBMs from Korean and imported origin, Korean and Brazil origin, and Korean and India origin, while additional comparisons were made among diets formulated on the basis of TAA and TIDAA. To enhance the interpretation of the results, the mean separations were analyzed using the Student-Newman-Keuls multiple range test. $P$ - values of less than 0.05 were considered statistically significant.

\section{RESULTS AND DISCUSSION}

\section{Growth Performance}

Growth performance of broilers fed diets containing SBM from different origin is presented in Table 3. Birds fed the Korean SBM had better $(P<0.05)$ weight gain (starter, finisher and overall), feed intake (starter, finisher and overall) and FCR (finisher and overall) when compared with birds fed imported SBM (India + Brazil). In addition, birds fed Korean SBM had better $(P<0.05)$ weight gain (starter, finisher and overall) feed intake and FCR (finisher and overall) than birds fed diets with Brazilian SBM. Also, weight gain (starter, finisher and overall), feed intake (starter, finisher and overall) and FCR(finisher and overall) were better $(P<0.05)$ in birds

Table 3. Effects of origin of soybean meal on growth performance of broilers

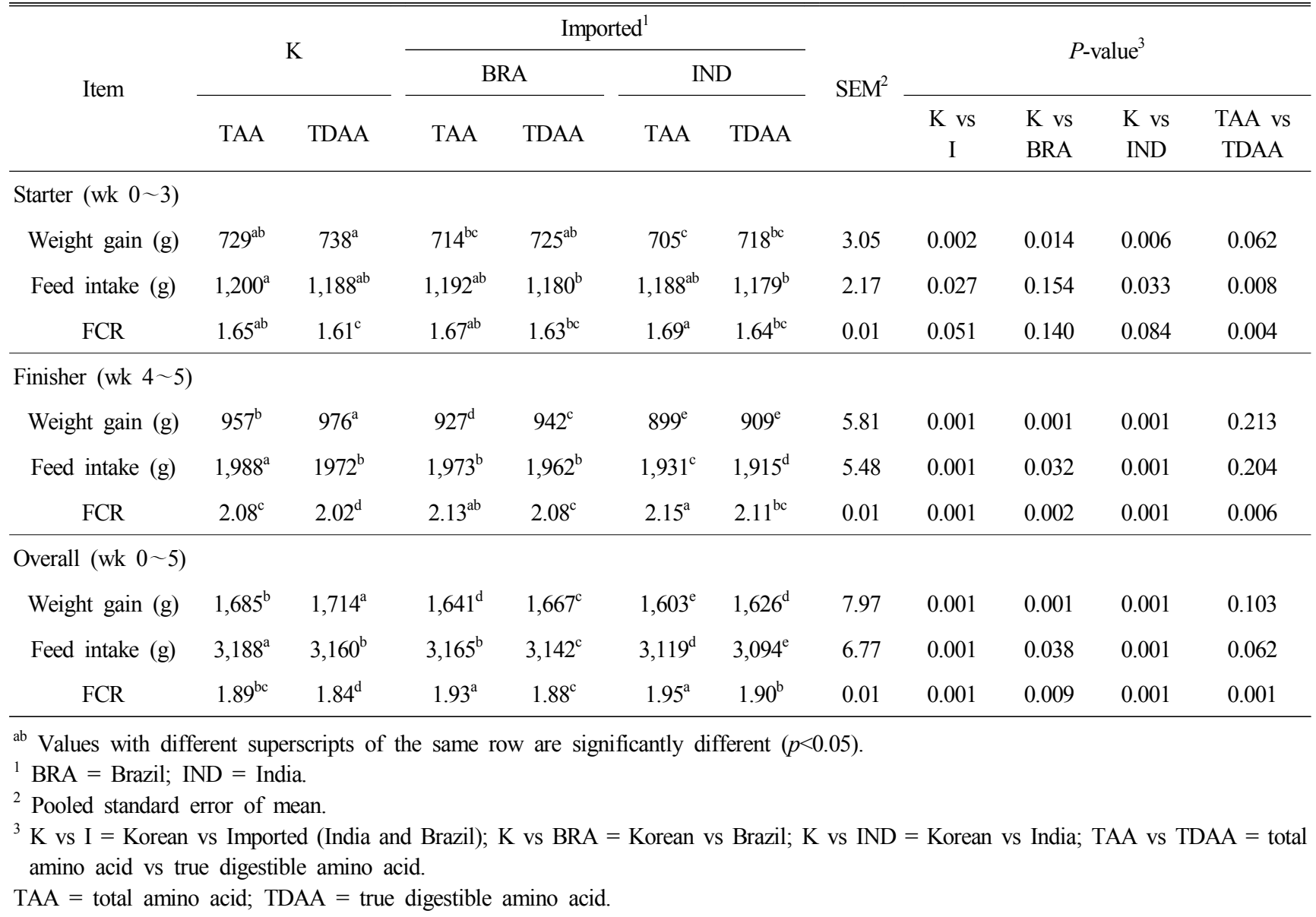


fed Korean SBM diet than birds fed diets containing Indian SBM. In comparison with diets formulated on TAA basis, diets formulated on TDAA basis resulted in greater $(P<0.05)$ feed intake (starter) and improved feed efficiency (starter, finisher and overall).

Soybean meal (SBM) is a major protein source in poultry feeds and one of the best quality ingredients. Because of the relatively good amino acid profile, it is usually used to balance the dietary amino acid levels with cereal grains and their byproducts in poultry feeds. In the present study, broiler fed the diets containing SBM originated form Korea had greater growth performance than broilers fed diets containing SBM originated from India or Brazil. Results obtained in the present study are in good agreement with data reported by Leeson et al. (1987), Lee et al. (1994) and Joo et al. (1994). Some of the previous studies also reported greater growth performance of broiler fed Korean native SBM than broiler fed SBM from Brazil or India (Park and Baik, 1997; Park et al., 2002). Greater performance of broiler fed Korean SBM might be due variation in amino acid profile of SBM from different origin and quality of nutrients due difference in storage period. In the present study, we used freshly prepared Korean SBM (one month before experimental feeding), while SBM imported from India and Brazil were prepared 4 months before the experimental feeding. It has reported that longer storage of SBM under unsecured condition results in decreased nutritional quality of SBM (Narayan et al., 1988). The discrepancy in growth performance of broilers fed diets containing SBM from different origin also might be due to variation in quality of SBM due to variation in soybean processing conditions, such as moisture, drying time and drying temperature. Over and under processing due to improper heating conditions can result in the production of poor quality SBM (Araba and Dale, 1990). Over processing of SBM results in a portion of the lysine being rendered unavailable for pigs due to Maillard reaction; whereas under processed SBM contains high concentration of antinutritional factors like trypsin inhibitors and saponins which decease the quality of SBM (Araba and Dale, 1990).

\section{Nutrient Retention}

Effects of origin of SBM on retention of energy and nutrients are presented in Table 4. During starter and finisher periods, the retention of $\mathrm{GE}$ and $\mathrm{CP}$ was greater $(P<0.05)$ in birds fed the diet containing Korean SBM as compared to birds fed the diets containing imported SBM (India + Brazil); while the retention of $\mathrm{CP}$ during finisher period was greater $(P<0.05)$ in birds fed diet containing Korean SBM than birds fed diet with Brazil SBM. Additionally, during starter and finisher periods, the retention of $\mathrm{DM}, \mathrm{GE}$ and $\mathrm{CP}$ was greater $(P<0.05)$ in birds fed diet having Korean SBM than birds fed India SBM diets. Broilers fed diets formulated on TDAA basis had greater $(P<0.05)$ retention of $\mathrm{CP}$ during starter period and DM, GE and $\mathrm{CP}$ during finisher period as compared to birds fed diets formulated on TAA basis.

In the present study, retention of nutrients in birds fed the Korean SBM diet was greater than birds fed Indian or Brazilian SBM diets. Several studies have shown considerable differences in nutrient content of SBM within and among geographic regions of the world (Baize, 1997; Grieshop et al., 2003). Different growing conditions and the use of various soybean genotypes in these regions can affect nutrient composition including contents of oligosaccharides, protease inhibitors and fiber (Baker and Stein, 2009; Kumar et al., 2010). As a result, nutrient retention in different batches of SBM fed to nonruminants may differ (Karr-Lilienthal et al., 2005). Moreover, regional variations in processing conditions of the soybeans may also affect nutrient digestibility of SBM (Sauer and Ozimek, 1986). Thermal treatment during SBM processing, for example, is frequently applied to inactivate residual contents of trypsin inhibitors in SBM (Qin et al., 1998). However, so called under-toasting during processing of SBM may result in incomplete removal of some anti-nutritional factors (Araba and Dale, 1990) which, in turn, may decrease nutrient digestibility in these SBM. In the present study, variation in nutrients retention among birds fed diet containing SBM from different origin might be due to variation in contents of oligosaccharides, protease inhibitors and fiber in SBM from different origin. Our results indicates that the use of the Korean SBM in broiler diets could be economically advantageous to the broiler production due to its excellent protein quality, greater growth performance and digestibility of nutrients as reported in present study.

In this study, the performance and retention of nutrient in 
Table 4. Effects of origin of soybean meal on apparent excreta nutrients digestibility of broilers

\begin{tabular}{|c|c|c|c|c|c|c|c|c|c|c|c|}
\hline \multirow{3}{*}{ Item } & \multirow{2}{*}{\multicolumn{2}{|c|}{$\mathrm{K}$}} & \multicolumn{4}{|c|}{ Imported $^{1}$} & \multirow{3}{*}{$\mathrm{SEM}^{2}$} & \multirow{2}{*}{\multicolumn{4}{|c|}{$P$-value ${ }^{3}$}} \\
\hline & & & \multicolumn{2}{|c|}{ BRA } & \multicolumn{2}{|c|}{ IND } & & & & & \\
\hline & TAA & TDAA & TAA & TDAA & TAA & TDAA & & $\begin{array}{c}\text { D vs } \\
\text { I }\end{array}$ & $\begin{array}{l}\mathrm{D} \text { vs } \\
\mathrm{BRA}\end{array}$ & $\begin{array}{l}\mathrm{D} \text { vs } \\
\mathrm{IND}\end{array}$ & $\begin{array}{c}\text { TAA vs } \\
\text { TDAA }\end{array}$ \\
\hline \multicolumn{12}{|c|}{ Starter $(\mathrm{d} 0 \sim 21)$} \\
\hline $\mathrm{DM}$ & $72.04^{\mathrm{ab}}$ & $72.29^{\mathrm{a}}$ & $71.92^{\mathrm{ab}}$ & $72.08^{\mathrm{ab}}$ & $71.62^{\mathrm{b}}$ & $71.95^{\mathrm{ab}}$ & 0.08 & 0.085 & 0.423 & 0.036 & 0.133 \\
\hline GE & $75.59^{\mathrm{ab}}$ & $75.79^{\mathrm{a}}$ & $75.20^{\mathrm{ab}}$ & $75.38^{\mathrm{ab}}$ & $75.07^{\mathrm{b}}$ & $75.12^{\mathrm{b}}$ & 0.09 & 0.001 & 0.061 & 0.002 & 0.433 \\
\hline $\mathrm{CP}$ & $65.37^{\mathrm{ab}}$ & $66.86^{\mathrm{a}}$ & $64.19^{\mathrm{bc}}$ & $66.46^{\mathrm{a}}$ & $63.47^{\mathrm{c}}$ & $64.46^{\mathrm{bc}}$ & 0.32 & 0.009 & 0.299 & 0.001 & 0.009 \\
\hline Ash & 39.70 & 39.80 & 39.21 & 39.52 & 38.42 & 38.88 & 0.33 & 0.301 & 0.565 & 0.258 & 0.669 \\
\hline $\mathrm{Ca}$ & 29.88 & 30.01 & 29.21 & 29.82 & 29.03 & 29.12 & 0.37 & 0.337 & 0.619 & 0.342 & 0.723 \\
\hline $\mathrm{P}$ & 27.58 & 27.30 & 27.58 & 27.55 & 27.14 & 27.13 & 0.51 & 0.937 & 0.937 & 0.761 & 0.920 \\
\hline \multicolumn{12}{|c|}{ Finisher (d 22 -35) } \\
\hline $\mathrm{DM}$ & $71.66^{\mathrm{bc}}$ & $72.78^{\mathrm{a}}$ & $71.46^{\mathrm{bc}}$ & $72.14^{\mathrm{ab}}$ & $71.04^{\mathrm{c}}$ & $71.77^{\mathrm{b}}$ & 0.14 & 0.071 & 0.213 & 0.035 & 0.001 \\
\hline GE & $75.56^{\mathrm{bc}}$ & $76.62^{\mathrm{a}}$ & $75.25^{\mathrm{bc}}$ & $75.80^{\mathrm{ab}}$ & $74.79^{\mathrm{c}}$ & $75.21^{b c}$ & 0.16 & 0.023 & 0.111 & 0.011 & 0.032 \\
\hline $\mathrm{CP}$ & $61.24^{\mathrm{ab}}$ & $62.76^{\mathrm{a}}$ & $60.51^{b c}$ & $61.29^{\mathrm{ab}}$ & $59.52^{\mathrm{c}}$ & $60.69^{\mathrm{bc}}$ & 0.27 & 0.007 & 0.039 & 0.010 & 0.032 \\
\hline Ash & 32.43 & 33.02 & 31.40 & 32.36 & 30.91 & 31.53 & 0.34 & 0.054 & 0.223 & 0.092 & 0.294 \\
\hline $\mathrm{Ca}$ & 28.85 & 29.86 & 27.11 & 27.96 & 27.73 & 27.32 & 0.56 & 0.253 & 0.274 & 0.262 & 0.680 \\
\hline $\mathrm{P}$ & $22.71^{\mathrm{ab}}$ & $23.56^{\mathrm{a}}$ & $22.05^{\mathrm{ab}}$ & $23.23^{\mathrm{ab}}$ & $21.13^{\mathrm{b}}$ & $22.04^{\mathrm{ab}}$ & 0.29 & b0.099 & 0.452 & 0.018 & 0.094 \\
\hline
\end{tabular}

${ }^{\mathrm{a} \sim \mathrm{c}}$ Values with different superscripts of the same row are significantly different $(p<0.05)$.

${ }^{1}$ BRA = Brazil; IND = India

${ }^{2}$ Pooled standard error of mean.

${ }^{3}$ K vs I = Korean vs Imported (India and Brazil); K vs BRA = Korean vs Brazil; K vs IND = Korean vs India; TAA vs TDAA = total amino acid vs true digestible amino acid.

birds fed diets formulated on the basis true ileal digestible amino acid (TIDAA) had greater than birds fed diets formulated on the basis of total amino acid (TAA). This might be due to greater availability of digestible amino acids in the diets formulated on TIDAA basis than TAA basis. Greater digestibility of amino acids and $\mathrm{CP}$ may result in more AA reaching organ systems of the birds which results into improved growth performance.

\section{Microbial Populations}

Data pertaining to effects of origin of SBM on excreta microflora population are presented in Table 5. Dietary treatments had no effect $(P>0.05)$ on the number of Clostridium spp., Bifidobacterium spp., Lactobacillus spp. and coliforms in the excreta during starter and finisher period. It has reported that dietary sources of fermentable carbohydrates and protein affect the host animal by improving its intestinal balance (Fuller, 1989) and creating gut micro-ecological conditions that suppress harmful microorganisms like Clostridium and Coliforms (Line et al., 1998; Pascual et al., 1999; Shim et al., 2010), and by favoring beneficial microorganisms like Lactobacillus and Bifidobacterium. In the present experiment, there were no differences in microbial population among birds fed diets containing SBM from different origin. This indicates that origin of SBM have no effects on fermentation pattern and intestinal microflora of broiler.

\section{Economic Analysis}

Economic analysis of broilers fed different SBM origin diets is presented in Table 6 . In spite of greater total weight 
Table 5. Effects of origin of soybean meal on fecal microbial populations of pigs $(\log 10 \mathrm{CFU} / \mathrm{g})$

\begin{tabular}{|c|c|c|c|c|c|c|c|c|c|c|c|}
\hline \multirow{3}{*}{ Item } & \multirow{2}{*}{\multicolumn{2}{|c|}{$\mathrm{K}$}} & \multicolumn{4}{|c|}{ Imported $^{1}$} & \multirow{3}{*}{$\mathrm{SEM}^{2}$} & \multirow{2}{*}{\multicolumn{4}{|c|}{$P$-value ${ }^{3}$}} \\
\hline & & & \multicolumn{2}{|c|}{ BRA } & \multicolumn{2}{|c|}{ IND } & & & & & \\
\hline & TAA & TDAA & TAA & TDAA & TAA & TDAA & & $\begin{array}{c}\text { D vs } \\
\text { I }\end{array}$ & $\begin{array}{l}\text { D vs } \\
\text { BRA }\end{array}$ & $\begin{array}{l}\text { D vs } \\
\text { IND }\end{array}$ & $\begin{array}{c}\text { TAA vs } \\
\text { TDAA }\end{array}$ \\
\hline \multicolumn{12}{|l|}{ Starter $(\mathrm{d} 0 \sim 21)$} \\
\hline Clostridium spp. & 8.63 & 8.59 & 8.67 & 8.67 & 8.63 & 8.68 & 0.012 & 0.658 & 0.728 & 0.672 & 0.870 \\
\hline Bifidobacterium spp. & 9.55 & 9.56 & 9.58 & 9.56 & 9.60 & 9.58 & 0.010 & 0.056 & 0.145 & 0.101 & 0.873 \\
\hline Lactobacillus spp. & 9.51 & 9.52 & 9.48 & 9.51 & 9.47 & 9.49 & 0.017 & 0.416 & 0.611 & 0.411 & 0.684 \\
\hline Coliforms & 7.58 & 7.60 & 7.60 & 7.61 & 7.66 & 7.61 & 0.019 & 0.091 & 0.265 & 0.094 & 0.819 \\
\hline \multicolumn{12}{|l|}{ Finisher $(\mathrm{d} 22 \sim 35)$} \\
\hline Clostridium spp. & 8.65 & 8.61 & 8.68 & 8.69 & 8.66 & 8.70 & 0.015 & 0.161 & 0.178 & 0.206 & 0.935 \\
\hline Bifidobacterium spp. & 9.54 & 9.56 & 9.53 & 9.53 & 9.55 & 9.54 & 0.009 & 0.511 & 0.380 & 0.860 & 0.824 \\
\hline Lactobacillus spp. & 9.48 & 9.49 & 9.44 & 9.48 & 9.44 & 9.45 & 0.015 & 0.286 & 0.649 & 0.148 & 0.410 \\
\hline Coliforms & 7.71 & 7.70 & 7.72 & 7.71 & 7.74 & 7.73 & 0.021 & 0.659 & 0.854 & 0.583 & 0.822 \\
\hline
\end{tabular}

${ }^{1} \mathrm{BRA}=$ Brazil; IND = India.

${ }^{2}$ Pooled standard error of mean.

${ }^{3} \mathrm{~K}$ vs I $=$ Korean vs Imported (India and Brazil); K vs BRA = Korean vs Brazil; K vs IND = Korean vs India; TAA vs TDAA = total amino acid vs true digestible amino acid.

Table 6. Production cost of broilers as affected by soybean meal origin

\begin{tabular}{|c|c|c|c|c|c|c|c|c|c|c|c|}
\hline \multirow{3}{*}{ Item $^{1}$} & \multirow{2}{*}{\multicolumn{2}{|c|}{$\mathrm{K}$}} & \multicolumn{4}{|c|}{ Imported $^{2}$} & \multirow{3}{*}{ SEM $^{3}$} & \multirow{2}{*}{\multicolumn{4}{|c|}{$P$-value ${ }^{4}$}} \\
\hline & & & \multicolumn{2}{|c|}{ BRA } & \multicolumn{2}{|c|}{ IND } & & & & & \\
\hline & TAA & TDAA & TAA & TDAA & TAA & TDAA & & $\begin{array}{c}\text { D vs } \\
\text { I }\end{array}$ & $\begin{array}{l}\text { D vs } \\
\text { BRA }\end{array}$ & $\begin{array}{l}\text { D vs } \\
\text { IND }\end{array}$ & $\begin{array}{c}\text { TAA vs } \\
\text { TDAA }\end{array}$ \\
\hline
\end{tabular}

\begin{tabular}{|c|c|c|c|c|c|c|c|c|c|c|c|}
\hline \multicolumn{12}{|l|}{ Starter $(\mathrm{d} 0 \sim 21)$} \\
\hline $\mathrm{FC}(\mathrm{W} / \mathrm{kg})$ & 544 & 537 & 530 & 522 & 528 & 520 & & & & & \\
\hline TWG (g/bird) & $728^{\mathrm{ab}}$ & $738^{\mathrm{a}}$ & $713^{\mathrm{bc}}$ & $725^{\mathrm{ab}}$ & $704^{\mathrm{c}}$ & $717^{\mathrm{bc}}$ & 3.04 & 0.002 & 0.014 & 0.006 & 0.062 \\
\hline TFI (g/bird) & $1,200^{\mathrm{a}}$ & $1,187^{\mathrm{ab}}$ & $1,192^{\mathrm{ab}}$ & $1,180^{\mathrm{b}}$ & $1,187^{\mathrm{ab}}$ & $1,179^{\mathrm{b}}$ & 2.17 & 0.027 & 0.154 & 0.033 & 0.008 \\
\hline FCG (W/kg gain) & $895^{\mathrm{a}}$ & $864^{\mathrm{bc}}$ & $886^{\mathrm{ab}}$ & $849^{c}$ & $890^{\mathrm{a}}$ & $855^{\mathrm{c}}$ & 4.67 & 0.317 & 0.257 & 0.563 & 0.001 \\
\hline \multicolumn{12}{|l|}{ Finisher (d 22 -35) } \\
\hline $\mathrm{FC}(\mathrm{W} / \mathrm{kg})$ & 521 & 516 & 512 & 505 & 509 & 503 & & & & & \\
\hline TWG (g/bird) & $956^{\mathrm{b}}$ & $975^{\mathrm{a}}$ & $926^{\mathrm{d}}$ & $941^{\mathrm{c}}$ & $898^{\mathrm{e}}$ & $908^{\mathrm{e}}$ & 5.80 & $<0.001$ & $<0.001$ & $<0.001$ & 0.213 \\
\hline TFI (g/bird) & $1,987^{\mathrm{a}}$ & $1,972^{\mathrm{b}}$ & $1,972^{\mathrm{b}}$ & $1,962^{\mathrm{b}}$ & $1,931^{\mathrm{c}}$ & $1,914^{\mathrm{d}}$ & 5.48 & 0.001 & 0.032 & $<0.001$ & 0.204 \\
\hline FCG (W/kg gain) & $1,084^{\mathrm{a}}$ & $1,044^{\mathrm{c}}$ & $1,090^{\mathrm{a}}$ & $1,052^{\mathrm{bc}}$ & $1,094^{\mathrm{a}}$ & $1,060^{\mathrm{b}}$ & 4.31 & 0.303 & 0.536 & 0.240 & $<0.001$ \\
\hline \multicolumn{12}{|l|}{ Overall (d $0 \sim 35)$} \\
\hline TWG (g/bird) & $1,685^{\mathrm{b}}$ & $1,713^{\mathrm{a}}$ & $1,640^{\mathrm{d}}$ & $1,667^{\mathrm{c}}$ & $1,603^{\mathrm{e}}$ & $1,626^{\mathrm{d}}$ & 7.97 & $<0.001$ & $<0.001$ & $<0.001$ & 0.103 \\
\hline TFI (g/bird) & $3,188^{\mathrm{a}}$ & $3,159^{\mathrm{b}}$ & $3,164^{b}$ & $3,142^{\mathrm{c}}$ & $3,118^{\mathrm{d}}$ & $3,094^{\mathrm{e}}$ & 6.76 & 0.001 & 0.038 & $<0.001$ & 0.062 \\
\hline FCG (W/kg gain) & $1,002^{\mathrm{a}}$ & $967^{\mathrm{b}}$ & $1,001^{\mathrm{a}}$ & $964^{\mathrm{b}}$ & $1,004^{\mathrm{a}}$ & $970^{\mathrm{b}}$ & 3.89 & 0.981 & 0.847 & 0.812 & $<0.001$ \\
\hline
\end{tabular}


Table 6. Production cost of broilers as affected by soybean meal origin

a $\sim$ e Values with different superscripts of the same row are significantly different $(p<0.05)$.

${ }^{1}$ FC, feed cost per kg; TWG, total weight gain per broiler; TFI, total feed intake per broiler; FCG, feed cost/kg body weight gain.

${ }^{2} \mathrm{BRA}=$ Brazil; IND $=$ India.

${ }^{3}$ Pooled standard error of mean.

${ }^{4} \mathrm{~K}$ vs I = Korean vs Imported (India and Brazil); K vs BRA = Korean vs Brazil; K vs IND = Korean vs India; TAA vs TDAA = total amino acid vs true digestible amino acid.

gain and total feed intake of birds fed Korean SBM containing diets in comparison with imported SBM from India and Brazil, the feed cost per kg body weight in birds did not differ $(P>0.05)$ among the treatment diets. However, formulating diets on TDAA basis resulted in lower $(P<0.05)$ feed cost per $\mathrm{kg}$ body when compared with diets formulated on TAA basis during starter, finisher and overall period. These results indicate that diets formulated on the TDAA basis are more economic than diets formulated on the basis of TAA.

\section{SUMMARY}

In the present study, the Korean SBM was more efficient than Brazil- and India-originated SBM in improving performance in broilers. These results indicate that domestic SBM has better nutrient digestibility than SBM imported from Brazil and India, which contributes to the improved performance of broilers. Therefore, based on the results of this experiment, it is recommended to use domestic SBM because of its excellent protein quality.

\section{ACKNOWLEDGEMENT}

The authors are thankful to the Institute of Animal Resources, Kangwon National University, Chuncheon, Republic of Korea for providing the technical facilities to conduct this experiment.

\section{REFERENCES}

AOAC 2007 Official Methods of Analysis. 18th ed. AOAC Int., Gaithersburg, MD.

Araba M, Dale N 1990 Evaluation of protein solubility as an indicator of over-processing soybean meal. Poultry Sci 69: 76-83.
ASA 2002 Soy Stats. A Reference Guide to Important Soybean Facts and Figures. American Soybean Association, St. Louis, MO.

Baize JC 1997 Results of USB study on SBM quality released. Soybean Meal Info Source 1:1-4.

Baker KM, Stein HH 2009 Amino acid digestibility and concentration of digestible and metabolizable energy in soybean meal produced from conventional, high-protein, or low-oligosaccharide varieties of soybeans and fed to growing pigs. J Anim Sci 87:2282-2290.

Choi JY, Shinde PL, Ingale SL, Kim JS, Kim YW, Kim KH, Kwon IK, Chae BJ 2011 Evaluation of multi-microbe probiotics prepared by submerged liquid or solid substrate fermentation and antibiotics in weaning pigs. Livest Sci 138:144-151.

Cromwell GL 2000 Utilization of soy products in swine diets. In Soy in Animal Nutrition. J. K. Drackley, ed Fed. Anim Sci Soc, Savoy, IL, pp. 258-282.

Eggum BO, Beames RM 1983 The nutritive value of seed proteins. In: Seed Proteins, Biochemistry, Genetics, Nutritive value. (Ed. E. Gottschalk and H. P. Muller). pp. 499531. Martinus Nijhof/Junk, Hague.

Fenton TW, Fenton M 1979 An improved method for chromic oxide determination in feed and feces. Can J Anim Sci 59:631-634.

Fuller R 1989 Probiotics in man and animals. J Appl Bacteriol $66: 365-378$

Grieshop CM, Fahey GC Jr 2001 Comparison of quality characteristics of soybean meals. J Agric Food Chem 60: 437-442.

Grieshop CM, Kadzere CT, Clapper GM, Flickinger EA, Bauer LL, Frazier RL, Fahey GC 2003 Chemical and nutritional characteristics of United States soybeans and soybean meals. J Agric Food Chem 51:7684-7691.

Joo YJ, Kang KR, Nham KT, Kang CW, Jung MS 1994 
Evaluation of nutritional quality of soybean oil meals as poultry feed stuffs. Kor J Anim Nutr Feed 18(5):340-345.

Karr-Lilienthal LK, Kadzere CT, Grieshop CM, Fahey GC Jr 2005 Chemical and nutritional properties of soybean carbohydrates as related to nonruminants: A review. Livest Prod Sci 97:1-12.

Kim IH, Hancock JD, Jones DB, Reddy PG 1999 Extrusion processing of low-inhibitor soybeans improves growth performance of early-weaned pigs. Asian Aust J Anim Sci 12:1251-1257.

Kumar V, Rani A, Goyal L, Dixit AK, Manjaya GJ, Dev J, Swamy M 2010 Sucrose and raffinose family oligosaccharides (RFOs) in soybean seeds as influenced by genotype and growing location. J Agric Food Chem 58: 5081-5085.

Lee H, Garlich JD 1992 Effect of overcooked soybean meal on chicken performance and amino acid availability. Poultry Sci 71:499-508.

Lee JH, Han IK, Ha JK, Kim JW, Kim IB 1994 The determination of amino acid digestibility of soybean meals in pigs. Kor J Anim Nutr Feed 18:354-362.

Leeson SJ, Attech O, Summers JD 1987 Effects of increasing dietary levels of commercially heated soybeans on performance, nutrient retention and carcass quality of broiler chickens. Can J Anim Sci 67:821-828.

Line, EJ, Bailey SJ, Cox NA, Stern NJ, Tompkins T 1998 Effect of yeast-supplemented feed on Salmonella and Campylobacter populations in broilers. Poultry Sci 77: 405-410.

Narayan R, Chauhan GS, Verma NS 1988 Changes in the quality of soybean during storage. Part 2 - Effect of soybean storage on the sensory qualities of the products made there from. Food Chem 30(3):181-190.

NRC 1994 Nutrient Requirement of Poultry. 9th Edn. National Academy Press, Washington, DC.
Park HS, Baik SH 1997 Comparison of two different soybean meal sources for broilers. ASA Feeding Trial Report. ASA, Korea.

Park YH, Kim HK, Kim HS, Lee HS, Shin IS, Whang KY 2002 Effects of three different soybean meal sources on layer and broiler performance. Asian Aust J Anim Sci 15:254-265.

Pascual M, Hugas M, Badiola JI, Monfort JM, Garriga M 1999 Lactobacillus salivarius CTC2197 prevents Salmonella enteritidis colonization in chickens. Appl Environ Microbiol 65:4981-4986.

Qin GX, Verstegen MWA, van der Poel AFB 1998 Effect of temperature and time during steam treatment on the protein quality of full - fat soybeans from different origins. J Sci Food Agric 77:393-398.

SAS Institute Inc. 1996 SAS/STAT Software: Changes and Enhancements through Release 6.11. SAS 412 Institute Inc., Cary, NC.

Sauer WC, Ozimek L 1986 Digestibility of amino acids in swine: Results and their practical applications. Livest Prod Sci $15: 367-388$.

Shim YH, Shinde PL, Choi JY, Kim JS, Seo DK, Pak JI, Chae BJ, Kwon IK 2010 Evaluation of multi-microbial probiotics produced by submerged liquid and solid substrate fermentation methods in broilers. Asian Aust J Anim Sci 23:521-529.

USDA 2009 Oilseeds: World Markets and Trade. Agric. Marketing Service, USDA, Washington, DC.

van Kempen TATG, van Heugten E, Moeser AJ, Muley NS, Sewalt VJH 2006 Selecting soybean meal characteristics preferred for swine nutrition. J Anim Sci 84:1387-1395.

Ward, NE 1996. Quality Considerations for Soybean Meal. ASA Technical Bulletin. MITA No. 195, 11. ASA, Singapore.

(접수: 2013. 5. 21, 수정: 2013. 6. 13, 채택: 2013. 6. 13) 